2. ECN Category

(mark one)

Supplemental

Direct Revision

Change ECN

Temporary

Standby

Supersedure

Cancel/Void
3. Originator's Name, Organization, MSIN, and Telephone No.

J.V. Nelson, Nuclear Safety, R3-26, 376-4480

[]

[x]

Spent Nuclear Fuel Project

9. Document Numbers Changed by this ECN

(includes sheet no. and rev.) HNF-SD-SNF-CSER-006, Rev. 1

\begin{tabular}{|c|c|}
\hline $\begin{array}{l}\text { 4. USQ Required? } \\
\text { [1 Yes [x] No }\end{array}$ & $\begin{array}{c}\text { 5. Date } \\
2 / 11 / 99 \\
1 / 20 / 99-\end{array}$ \\
\hline $\begin{array}{c}\text { 7. Bldg/Sys./Fac. No. } \\
\text { W-44] }\end{array}$ & $\begin{array}{c}\text { 8. Approval Designator } \\
\text { S }\end{array}$ \\
\hline $\begin{array}{c}\text { 10. Related ECN No(s). } \\
637181\end{array}$ & 11. Related PO No. \\
N/A
\end{tabular}

12a. Modification Work

[ ] Yes (fill out Blk, 12b)

[x] No (NA Blks. 12b, 12c, 12d)

\begin{tabular}{l|l}
$\begin{array}{l}\text { 12b. Work Package } \\
\text { No. }\end{array}$ & $\begin{array}{l}12 \mathrm{c} . \text { Modification Work Complete } \\
\text { N/A }\end{array}$ \\
$\begin{array}{c}\text { N/A } \\
\text { Design Authority/Cog. Engineer } \\
\text { Signature \& Date }\end{array}$
\end{tabular}

12d. Restored to Original Condition (Temp. or Standby ECN only)

N/A

Design Authority/Cog. Engineer Signature \& Date

13a. Description of Change

13b. Design Baseline Document? [ ] Yes [X] No

This revision incorporates new data from Revision 1 of HNF-SD-SNF-CSER-009, "Calculation of $1.25 \%{ }^{235} \mathrm{U}$ Enriched $\mathrm{UO}_{2}$ Solution Safe Slab, Safe Cylinder Diameter, Minimum Safe Mass, and Ion Exchange Module for the CVDF," and evaluates the need for criticality instrumentation in the CVDF. Editorial changes were also made to clarify the document and to incorporate comments from CVDF operations personnel who reviewed the document.

No USQ is required because this ECN does not change the facility or its procedures.

\begin{tabular}{|llllllll}
\hline 14a. Justification (mark one) & & & & & \\
Criteria Change & {[]} & Design Improvement & [X] & Environmental & [] & Facility Deactivation \\
As-Found & {[]} & Facilitate Const & [] & Const. Error/Omission & [] & Design Error/Omission & [] \\
\hline
\end{tabular}

14b. Justification Details

See box 13a.

15. Distribution (include name, MSI, and no: of copies)

See attached distribution coversheet.

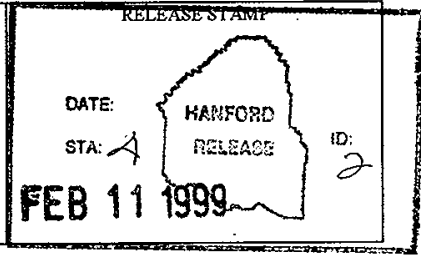

A-7900-013-2 (05/96) GEFO95 


\section{Criticality Safety Evaluation Report for the Cold Vacuum Drying Facility's Process Water Handling System}

\section{J.V. Nelson}

Fluor Daniel Northwest, Inc., Richland, WA 99352

U.S. Department of Energy Contract DE-AC06-96RL13200

ECN: 637198

Org Code: 403

B\&R Code: $39 \mathrm{EW} 40400$
UC: 620

Charge Code: $105568 / C B 80$

Total Pages: 46

Key Words: Criticality, Safety, Cold Vacuum Drying Facility, Water, Handling, System

Abstract: This report addresses the criticality concerns associated with process water handling in the Cold Vacuum Drying Facility. The controls and limitations on equipment design and operations to control potential criticality occurrences are identified.

TRADEMARK DISCLAIMER. Reference herein to any specific commercial product, process, or service by trade name, trademark, manufacturer, or otherwise, does not necessarily constinute or imply its endorsement, recommendation, or favoring by the United States Government or any agency thereof or its contractors or subcontractors.

Printed in the United States of America. To obtain copies of this document, contact: Document Control Services, P.0. Box 950, Mailstop H6-08, Richland WA 99352, Phone (509) 372-2420; Fax (509) 376-4989.
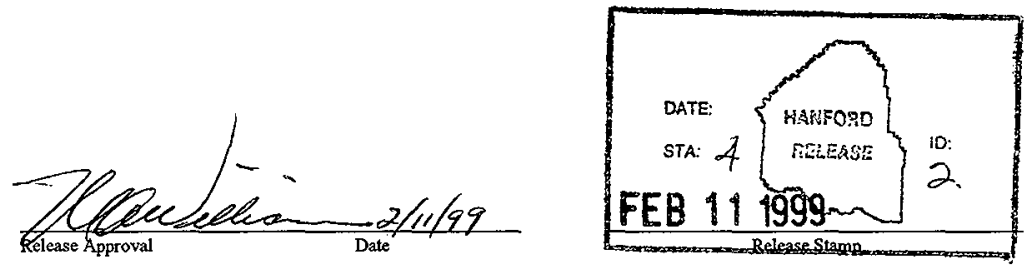

\section{Approved for Public Release}




\section{RECORD OF REVISION}

(1) Document Number

HNF-SD-SNF-CSER-006,

Rev. 2

(2) Title

Criticality Safety Evaluation Report for the Cold Vacuum Drying Facility's Process Water Handling System

\section{CHANGE CONTROL RECORD}

\begin{tabular}{|c|c|c|c|}
\hline \multicolumn{4}{|c|}{ CHANGE CONTROL RECORD } \\
\hline \multirow[t]{2}{*}{ (3) Revision } & \multirow{2}{*}{ (4) Description of Change - Replace, Add, and Delete Pages } & \multicolumn{2}{|c|}{ Authorized for Release } \\
\hline & & (5) Cog. Engr. & (6) Cog. Mgr. \\
\hline & (7) & & \\
\hline 0 & EDT: 624278 & & \\
\hline 1 & $\begin{array}{l}\text { ECN: } \mathbf{6 3 7 1 8 1} \\
\text { Revised the criticality safety evaluation report for the updated } \\
\text { design of the process water conditioning system. }\end{array}$ & & \\
\hline 2 RS & $\begin{array}{l}\text { ECN: } 637198 \\
\text { Complete revision to incorporate new data in Revision I of } \\
H N F-S D-S N F-C S E R-009, \text { to evaluate the need for criticality } \\
\text { instrumentation, to incorporate comments from CVDF } \\
\text { operations personnel, and to clarify the document. }\end{array}$ & $\begin{array}{l}\text { J.V. Nelson } \\
91 / 79+19 / 99\end{array}$ & $\begin{array}{l}\text { R.P. Omberg } \\
P P Q_{2} / 11 / 99\end{array}$ \\
\hline & & & \\
\hline & & & \\
\hline & & & \\
\hline & & & \\
\hline & & & \\
\hline
\end{tabular}


HNF-SD-SNF-CSER-006 REV 2

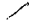 \\ CRITICALITY SÁFETY EVALUATION REPORT FOR THE COLD VACUUM DRYING FACILITY'S PROCESS \\ WATER CONDITIONING SYSTEM}

HNF-SD-SNF-CSER-006

Revision 2

January 1999 
HNF-SD-SNF-CSER-006 REV 2

This page intentionally left blank. 


\section{CONTENTS}

1.0 INTRODUCTION AND SUMMARY OF LIMITS AND CONTROLS . . . . . . . 1-1

1.1 OVERVIEW . . . . . . . . . . . . . . . . . . . . . . . . . . 1-1

1.2 LIMTTS, CONTROLS, AND ENGINEERED FEATURES $\ldots \ldots \ldots \ldots \ldots \ldots 1-1$

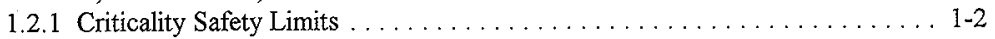

1.2 .2 Administrative Controls ......................... 1-3

1.2.3 Engineered Features and Dimensions Requiring Quality Control

Verification ............................ $1-4$

2.0 FACILITY AND OPERATION DESCRIPTION $\ldots \ldots \ldots \ldots \ldots \ldots \ldots \ldots \ldots \ldots$ 2-1

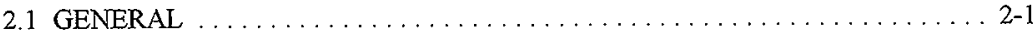

2.2 PROCESS WATER CONDITIONING SYSTEM $\ldots \ldots \ldots \ldots \ldots \ldots \ldots \ldots 2-2$

2.3 FISSIONABLE MATERIAL CHARACTERISTICS $\ldots \ldots \ldots \ldots \ldots \ldots \ldots .2-3$

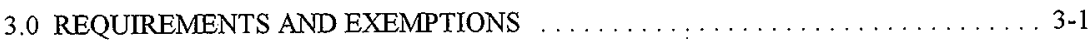

3.1 CRITICALITY SAFETY CRITERION FOR REACTIVITY CALCULATIONS . . 3-1

3.2 APPLICATION OF THE CRITICALITY SAFETY CRITERION . . . . . . . . 3-1

4.0 METHOD OF ANALYSIS AND RESULTS $\ldots \ldots \ldots \ldots \ldots \ldots \ldots \ldots \ldots \ldots . . \ldots \ldots$

4.1 QUALIFICATION OF THE ANALYSIS METHOD $\ldots \ldots \ldots \ldots \ldots \ldots \ldots 4-1$

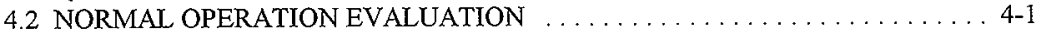

4.2. I Process Water Conditioning Receiver Tanks .............. 4-4

4.2.2 Process Water Conditioning lon Exchange Module . . . . . . . . . . . 4-4

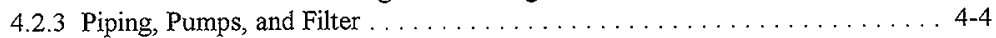

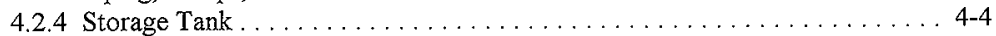

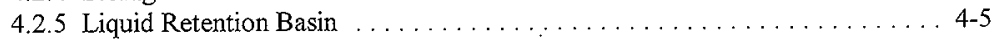

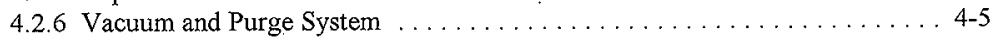

5.0 CONTINGENCY ANALYSIS . . . . . . . . . . . . . . . . . . 5-1

5.1 POTENTIAL ERROR OR FAILURE SITUATIONS $\ldots \ldots \ldots \ldots \ldots \ldots \ldots .5-1$

5.2 REQUTREMENT FOR CRITICALITY INSTRUMENTATION . . . . . . . . 5-3

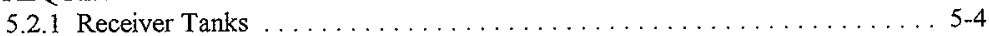

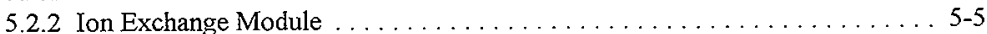

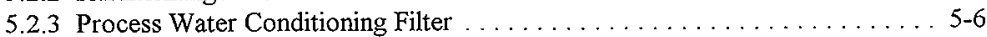

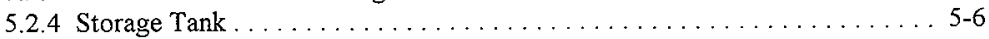

5.2 .5 Other Components ........................ 5-7

5.2.6 Worst-Case Spill on Process Water Conditioning Room Floor . . . . . . . . 5-7

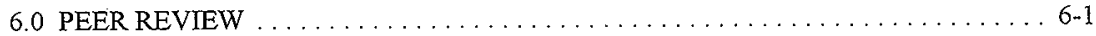

7.0 REFERENCES ............................... 7.1

APPENDIX A - LISTINGS OF MCNP INPUT FILES $\ldots \ldots \ldots \ldots \ldots \ldots \ldots \ldots$ A-1 
HNF-SD-SNF-CSER-006 REV 2

\section{LIST OF FIGURES}

2-1 Cold Vacuum Drying Facility Process Water Conditioning System Flow Diagram . . . 2-6

5-1 Cold Vacuum Drying Facility Process Water Conditioning Room Dose Rates at 90 Centimeters Elevation from 15 Kilograms of Uranium in Receiver Tanks . . . . . . 5-8

5-2 Cold Vacuum Drying Facility Process Water Conditioning Room Dose Rates at 90 Centimeters Elevation from 15 Kilograms of Uranium in a 5,000-Gallon Tank . . . . . 5-9

\section{LIST OF TABLES}

2-1 Design Parameters and Assumptions. $2-3$

2-2 Equipment Capacities. 2-4

4-1 Normal and Off-Normal Conditions of Cold Vacuum Drying Facility Equipment 4-2 


\section{ACRONYMS AND ABBREVIATIONS}

CSER criticality safety evaluation report

CVDF Cold Vacuum Drying Facility

IXM ion exchange module

MCO multi-canister overpack

PWC process water conditioning

RCT radiological control technician

SPR single pass reactor 
HNF-SD-SNF-CSER-006 REV 2

This page intentionally left blank. 
HNF-SD-SNF-CSER-006 REV 2

\subsection{INTRODUCTION AND SUMMARY OF LIMITS AND CONTROLS}

The scope of this report is limited to addressing the criticality concerns associated with water drained from multi-canister overpacks (MCOs) and processed in the Cold Vacuum Drying Facility (CVDF). The criticality evaluation of the fuel in the MCOs is reported in HNF-SD-SNF-CSER-005, Criticality Safety Evaluation Report for Spent Nuclear Fuel Processing and Storage Facilities (Schwinkendorf 1997).

\subsection{OVERVIEW}

Spent muclear fuel, consisting of $N$ Reactor fuel and some single pass reactor (SPR) fuel, is removed from existing canisters in both the $\mathrm{K}$ East and $\mathrm{K}$ West Basins and loaded into MCOs underwater in the K Basin pools. Each MCO is housed in a shipping cask, and the annulus between the exterior of the MCO and the interior of the shipping cask is filled with clean water. The loaded shipping cask is transported to the CVDF, located near the K Basins, and the free water is removed from the interior of the MCO. After the bulk of the free water is removed, any remaining free liquid is removed by drawing a vacuum on the MCO's interior. When cold vacuum drying has been completed, the water is drained from the shipping cask annulus, the $\mathrm{MCO}$ is filled with an inert cover gas, the lid is replaced on the shipping cask, and the shipping cask is transported to the Canister Storage Building.

Water removed from an MCO contains fissionable materials from metallic uranium corrosion. The water is first collected in geometrically safe, process water conditioning. (PWC) system receiver tanks. After the $\mathrm{MCO}$ has been drained and the piping flushed and drained, the water in the receiver tank is tested, then filtered, demineralized, and transferred to a 5,000 gal cylindrical storage tank. The processed water is removed from the storage tank and returned to the $\mathrm{K}$ Basins by truck after 15 to $20 \mathrm{MCOs}$ have been processed (i.e., when the tank is full).

\subsection{LIMITS, CONTROLS, AND ENGINEERED FEATURES}

The analyses reported in this criticality safety evaluation report (CSER) show that criticality is incredible in PWC system equipment at the CVDF for all normal operating and off-normal scenarios that satisfy the double contingency criterion. This assumes only that the fissionable material in the water is from uranium fuel not exceeding an average initial enrichment of $1.25 \mathrm{wt} \%{ }^{235} \mathrm{U}$. The following criticality limits are provided for information only. No administrative controls or engineered features specifically for criticality prevention need be in place. Physical limitations on the fissionable mass that can accumulate in the PWC room and restrictive radiation limits guarantee that a criticality will not occur. These limitations are described in Chapters 4.0 and 5.0 . 


\subsubsection{Criticality Safety Limits}

The mass limit (limit 1 below) is provided for information only; other physical and administrative limits are more restrictive. The geometry limits (limits 2, 3, and 4) are not required because a criticality in the PWC room is incredible, but they provide geometry control to protect against a beyond design basis event.

Limit 1 The total actinide mass (uranium plus transuranic products of irradiation) present in the PWC system at any time must not exceed $875 \mathrm{~kg}$.

Basis This limit applies to the sum of the actinide masses in all PWC components. The limit is the maximum safe mass of unirradiated uranium in homogenized $\mathrm{UO}_{2}$ at $1.25 \mathrm{wt} \%$ ${ }^{235} \mathrm{U}$ enrichment that will not exceed a $\mathrm{k}_{\text {eff }}$ of 0.95 under idealized conditions (Nelson 1998). From a reactivity standpoint, this safe mass is more limiting than all possible variations in geometry and enrichments at or below the limit of $1.25 \mathrm{wt} \%$ ${ }^{235} \mathrm{U}$, or transuranic isotopes produced in exposed fuel in the MCOs (Schwinkendorf 1997). It is thus very conservative for this application. Even so, the limit far exceeds the maximum mass that can realistically accumulate in the PWC room. Also, other operational limits and administrative controls are much more restrictive than this criticality limit.

Limit 2 The inner diameter of the parallel cylindrical receiver tanks must not exceed 23.5 in., and the two tanks must have more than 8 in. of separation between their outer surfaces.

Basis The maximum safe inner diameter and minimum separation of the cylindrical vessels was determined for a homogenized mixture of $1.25 \mathrm{wt} \%{ }^{235} \mathrm{U}$ enriched $\mathrm{UO}_{2}$ at optimum water moderation and reflection. The reactivity of these vessels will be less than the criticality safety limit for all possible combinations of moderator materials, reflection, and enrichments with all credible buildup levels of transuranic isotopes at or below the limit of $1.25 \mathrm{wt} \%{ }^{235} \mathrm{U}$ enrichment.

This limit is implemented by the design of the CVDF PWC system and quality control inspections to verify construction. Compliance with this limit is not essential to criticality safety in the PWC room. It is, however, a prudent defense-in-depth limit that will protect against the beyond design basis event in which more than $875 \mathrm{~kg}$ of actinides are extracted from an $\mathrm{MCO}$ or otherwise accumulate in the receiver tanks.

Limit 3 The inner diameter of any filters, pumps, or piping must not exceed 23.5 in.

Basis The safe inner diameter limit of vessels was determined for a homogenized mixture of $1.25 \mathrm{wt} \%{ }^{235} \mathrm{U}$-enriched $\mathrm{UO}_{2}$ at optimum water moderation and total reflection. The reactivity of these vessels will be less than the criticality safety limit for all possible 
combinations of moderator materials, reflection, and enrichments with all credible buildup levels of transuranic isotopes at or below the limit of $1.25 \mathrm{wt} \%{ }^{235} \mathrm{U}$ enrichment.

This limit is implemented by the design of the CVDF PWC system. Again, this limit is not essential to criticality safety in the PWC room.

Limit 4 The ion exchange module (IXM) consists of six vessels fully encased in concrete. The vessels are placed in pairs forming three rows in square array. The ion exchange vessels must not exceed a maximum outer height of 42.25 in. or a diameter that corresponds to 16-in. pipe, and must have a wall thickness at least that of schedule 30 pipe (Arora 1995).

Basis The IXM has been analyzed for its specific geometry. The criticality safety limit will not be exceeded for all combinations of fissionable material mass, and water and resin moderation for enrichments up to $1.25 \mathrm{wt} \%{ }^{235} \mathrm{U}$.

This limit is implemented by the design of the IXMs and quality control inspections of their construction. Again, this limit is not essential to criticality safety in the PWC room because it is inconceivable under realistic assumptions that limit 1 would ever be exceeded. Under normal conditions, the actinide inventory in the IXMs will be limited to $2 \mathrm{~kg}$, so they do not have to be disposed of as transuranic waste. However, the critically favorable design of the IXMs again provides defense in depth without additional cost.

\subsubsection{Administrative Controls}

Physical limitations and administrative controls in the form of sampling and monitoring requirements assure compliance with limit 1 . These requirements, which have been placed on the PWC system for reasons other than criticality control, are listed below.

Requirement 1 Take samples upstream and downstream of the IXMs and from the inlet to the storage tank to determine concentrations and accumulations of fissionable materials and effectiveness of PWC equipment.

Requirement 2 Monitor radiation levels in the PWC room.

Requirement 3 Prevent buildup of fissionable material in the storage tank.

In addition, an accountability system maintains a running total of the fissionable material in the system.

The use of administrative controls to implement limit 1 is justified because an excessive fissionable material buildup in the storage tank is the only situation in which a criticality event can 
possibly occur. Other components in the PWC room have, by design, critically favorable geometries. While a criticality caused by a large spill onto the PWC room floor is theoretically possible, an incredible quantity of fissionable material would be required.

The buildup of fissionable material in the storage tank is estimated and tracked in accordance with administrative procedures. Routine sampling and monitoring is a cost-effective method of ensuring compliance with limit 1 . A single failure of any administrative control could not result in a criticality limit being violated, let alone result in a criticality. Based on the estimated maximum of $13.2 \mathrm{~kg}$ of fuel actinides extracted from an $\mathrm{MCO}$, a criticality accident would only be possible through repeated failure of administrative controls over several months. Also, based on as-low-as-reasonably-achievable exposure studies (Miska and Nelson 1998), radiation levels in the PWC room will reach unacceptable levels long before any criticality limits are approached.

\subsubsection{Engineered Features and Dimensions Requiring Quality Control Verification}

The following engineered features implement limits 2,3 , and 4 and require quality control verification. Again, these limits are not essential to criticality prevention in the PWC room, but are prudent, cost-effective measures to protect against a beyond design basis accident. Because the components listed below are not required for criticality prevention, they must meet only general service construction requirements.

1.2.3.1 Process Water Conditioning Receiver Tank Diameter. The PWC receiver tank's inner diameter shall not exceed $23.5 \mathrm{in}$. for a single tank or two tanks separated by at least 8 in. This requirement implements limit 2.

1.2.3.2 Filter, Pump, and Piping Diameters. The inner diameters of the filter, pump, and piping shall not exceed 23.5 in. This requirement implements limit 3.

1.2.3.3 Demineralizer Vessel Dimensions. Each demineralizer vessel shall have a maximum outer height of 42.25 in., a nominal diameter that corresponds to 16-in. pipe, and a minimum wall thickness of at least that of schedule 30 pipe. These requirements implements limit 4 . 
HNF-SD-SNF-CSER-006 REV 2

\subsection{FACILITY AND OPERATION DESCRIPTION}

\subsection{GENERAL}

The CVDF is used to remove free water from the spent nuclear fuel contained in each MCO and to vacuum dry the spent nuclear fuel before it is transferred to the Canister Storage Building. A shipping cask containing an empty $\mathrm{MCO}$ is loaded with fuel at the $\mathrm{K}$ Basins, removed from the basin, loaded onto a transport trailer, and transported to the CVDF. Processing occurs in one of the process bays at the CVDF with the loaded shipping cask remaining on the transport trailer. Water is drained from the MCO into the PWC system. Internal MCO temperatures are maintained within limits by the tempered water (annulus) system, which circulates water through the cask annulus during the entire process. Following the draining step, the MCO is vacuum dried to remove as much additional water as feasible. At the end of the vacuum drying process, the MCO vapor is tested for acceptable water content. The cask annulus is then drained and the cask sealed. After sealing, the cask is transported to the Canister Storage Building.

The CVDF is housed in a separate new structure located in the Hanford Site's $100 \mathrm{~K}$ Area. The building comprises four areas: the processing bays, the PWC room, the transfer corridor and auxiliary spaces, and the administrative area. The processing bays house the vacuum and purge system and the tempered water (annulus) system used for MCO drying operations. The PWC room houses the PWC receiver tanks, IXMs, pumps, and particulate filter that receive and process the contaminated water from the MCOs. A 5,000-gal cylindrical tank for storing demineralized but still radiologically contaminated water from the MCOs also is located in the PWC room. The transfer corridor houses change rooms, which provide separate access to each processing bay, various operations support rooms, the pipe runs, and the heating, ventilating and air conditioning ducting to the process bays.

Each processing bay has a single process equipment skid that contains the components of the vacuum and purge system and the tempered water (annulus) system. The vacuum and purge system is connected to an $\mathrm{MCO}$ through hoses attached to the process hood. The tempered water (annulus) system is connected to the cask annulus and includes a hot and chilled water system that establishes and controls the temperature of the $\mathrm{MCO}$ during the drying process. Water circulates through the cask annulus throughout processing.

During draining, about 130 gal of water is drawn from the bottom of the MCO through a long axial tube down the center of the $\mathrm{MCO}$, and purge gas is supplied through the top of the MCO. The water is drawn via the water jet ejector into the receiver tank loop, which cycles from the receiver tanks, through one of the IXMs, and back into the receiver tanks. Following free water removal, the MCO is purged with helium to dry the fuel. After the MCO is drained, the connections to the MCO are flushed to the receiver tanks with clean water to remove residual material in the piping. When this step is completed, the receiver tanks contain about 300 gal of water. Residual water removed from the vacuum and purge system is collected in a condenser and then drained to a small, 7-gal collection tank and pumped to the PWC receiver tanks. Following vacuum drying, the piping is disconnected, and the annulus is drained. 
HNF-SD-SNF-CSER-006 REV 2

Liquid spills, sprays, and leaks within each process bay are confined by the use of a liquid retention basin provided with the process equipment skids. The PWC skid in the PWC room has a similar liquid retention basin.

\subsection{PROCESS WATER CONDITIONING SYSTEM}

The CVDF PWC system consists of the following components:

- A water jet ejector to pump liquid from the MCO

- Receiver tanks to hold the water from the MCO

- Pumps to run the water jet ejector and pump liquid from the receiver tanks

- Two IXMs to remove ions from the liquid

- A filter to remove particulate

- A storage tank to hold the processed water.

The liquid pumped into the receiver tanks is circulated and recirculated through one of the IXMs. When the liquid has been sufficiently cleaned by the IXM, it is pumped from the receiver tank, through the IXM, through the filter, and into the 5,000-gal storage tank. The particulate filter, located downstream of the IXMs, prevents an inadvertent flow of fissionable materials to the storage tank should an IXM vessel fail. Fissionable materials from such a release will thus be retained in the safe geometry of the filter. The water collected in the storage tank is transferred to a tanker truck when the tank is full (after 15 to $20 \mathrm{MCO}$ have been processed) and taken to the $\mathrm{K}$ Basins. The process flow is illustrated in Figure 2-1.

The spent fuel is cleaned before it is shipped from the $\mathrm{K}$ Basins, and most of the particulate and corrosion products are removed. It is unlikely that much of the particulate remaining on the fuel after cleaning will be removed when the MCO is drained. Particles with diameters greater than $2 \mathrm{~mm}$ are prevented from entering the PWC system by a screen on the bottom of the long axial process tube. In addition, the combination of the helium pressure and water jet ejector suction is not sufficient to force large fuel particles into the PWC system. Material entering the system will have to be in suspension.

It is therefore assumed that the particulate not removed from the spent fuel during washing will remain in the MCO after draining at CVDF, but it also is assumed that all of the fiel oxide particles formed after cleaning are small enough to become suspended in the flow with the process water. Thus, the amount of particulate transported in the process water is equivalent to the amount of fuel oxidized after cleaning. This amount is estimated to be $13.2 \mathrm{~kg}$ of actinides at most (see Table 2-1). The flakes or particles that may exist in the process water are highly permeable and water-filled, and a homogeneous model of the oxide-water solution is appropriate. 
Table 2-1. Design Parameters and Assumptions.

\begin{tabular}{|l|c|c|}
\hline \multicolumn{1}{|c|}{ Parameter description } & Value & $\begin{array}{c}\text { Bounding value (safety } \\
\text { and accident limits) }\end{array}$ \\
\hline $\begin{array}{l}\text { Initial (unirradiated) fuel enrichment } \\
\text { and condition in the K Basins }\end{array}$ & $\begin{array}{c}\leq 1.25 \mathrm{wt} \%{ }^{235} \mathrm{U}, 99.8 \% \\
\text { of which has been } \\
\text { irradiated }\end{array}$ & $\begin{array}{c}1.25 \mathrm{wt} \%{ }^{235} \mathrm{U}, \\
\text { fresh }\end{array}$ \\
\hline $\begin{array}{l}\text { Fuel particulate remaining in MCO } \\
\text { after washing at K Basins* }\end{array}$ & $\begin{array}{c}4.8 \mathrm{~kg} \text { oxides } \\
\text { containing } 4.2 \mathrm{~kg} \\
\text { actinides }\end{array}$ & $\begin{array}{c}21 \mathrm{~kg} \text { oxides containing } \\
18.5 \mathrm{~kg} \text { actinides }\end{array}$ \\
\hline $\begin{array}{l}\text { Oxidized fuel particulate produced in } \\
\text { an MCO between washing at } \\
\text { K Basins and draining at CVDF* }\end{array}$ & $<100 \mathrm{~g}$ & $\begin{array}{c}15 \mathrm{~kg} \text { oxides containing } \\
13.2 \mathrm{~kg} \text { actinides }\end{array}$ \\
\hline $\begin{array}{l}\text { Actinides in the process water drained } \\
\text { from an MCO (estimated) }\end{array}$ & $<100 \mathrm{~g}$ & $13.2 \mathrm{~kg}$ \\
\hline $\begin{array}{l}\text { Actinides entrapped in IXM } \\
\text { under normal conditions }\end{array}$ & $<2 \mathrm{~kg}$ & $15 \mathrm{~kg}$ (assumed) \\
\hline Actinides entrapped in the filter & $<100 \mathrm{~g}$ & $\mathrm{~kg}$ \\
\hline
\end{tabular}

*Crowe, R. D., S. D. Kopelic, M. G. Piepho, P. D. Rittmann, D. L. Scott, and W. T. Watson, 1998, Cold Vacuum Drying Facility Design Basis Accident Analysis Documentation, HNF-2770, Rev. 0, Fluor Daniel Hanford, Incorporated, Richland, Washington.

$\mathrm{CVDF}=$ Cold Vacuum Drying Facility

IXM $=$ ion exchange module .

$\mathrm{MCO}=$ multi-canister overpack.

The design conditions, assumptions, and equipment capacities used to evaluate the PWC equipment during normal operation and for contingencies considered in this evaluation are listed in Tables 2-1 and 2-2. The uranium and actinide products of irradiation are conservatively represented in the criticality analyses by uranium enriched to $1.25 \mathrm{wt} \%{ }^{235} \mathrm{U}$, as described in Section 2.3.

\subsection{FISSIONABLE MATERIAL CHARACTERISTICS}

The spent nuclear fuel loaded into the MCOs at the K Basins is primarily spent $\mathrm{N}$ Reactor fuel, which has a maximum uranium entichment of $1.25 \mathrm{wt} \%{ }^{235} \mathrm{U}$. One MCO will contain the small amount of SPR fuel remaining in the K Basins. Initial enrichment of the SPR fuel varies from depleted to $2.1 \mathrm{wt} \%{ }^{235} \mathrm{U}$, the highest enrichment used in special irradiations. Detailed descriptions of these fuels are contained in HNF-SD-SNF-TI-009, 105-K Basin Material Design Basis Feed Description for Spent Nuclear Fuel Project Facilities (Praga 1998). 
HNF-SD-SNF-CSER-006 REV 2

Table 2-2. Equipment Capacities.

\begin{tabular}{|l|c|c|}
\hline \multicolumn{1}{|c|}{ Parameter description } & Estimated value & $\begin{array}{c}\text { Upper bounding value } \\
\text { (safety and accident } \\
\text { limits) }\end{array}$ \\
\hline Total MCOs to be processed & 440 & 440 \\
\hline MCO process water volume & $130 \mathrm{gal}$ & $180 \mathrm{gal}$ \\
\hline Receiver tank volume & $300 \mathrm{gal}$ & $300 \mathrm{gal}$ \\
\hline $\begin{array}{l}\text { Liquid in receiver tank when ready to } \\
\text { receive MCO process water }\end{array}$ & $\begin{array}{c}32 \mathrm{gal} \\
(10.7 \% \mathrm{filled})\end{array}$ & $32 \mathrm{gal}$ \\
\hline Filter tank volume & $3.2 \mathrm{gal}$ & $3.2 \mathrm{gal}$ \\
\hline Ion exchange column volume & $37 \mathrm{gal}$ & $37 \mathrm{gal}$ \\
\hline $\begin{array}{l}\text { Cylindrical storage tank: } \\
\text { Volume } \\
\text { Inner diameter }\end{array}$ & $5,000 \mathrm{gal}$ & $5,000 \mathrm{gal}$ \\
Height & $119.3 \mathrm{in}$. & $119.3 \mathrm{in}$. \\
$103.4 \mathrm{in}$. \\
\hline
\end{tabular}

$\mathrm{MCO}=$ multi-canister overpack.

The highest known enrichment of SPR fuel in the $\mathrm{K}$ Basins is $0.95 \mathrm{wt} \%{ }^{235} \mathrm{U}$. However a small quantity of SPR fuel ( 47 pieces, weighing a total of $106 \mathrm{~kg}$ ) is of unknown enrichment. The highest enrichment is not expected to be over $1.25 \mathrm{wt} \%{ }^{235} \mathrm{U}$, but in the criticality analysis of the MCO (Schwinkendorf 1997), the unknown SPR fuel was conservatively assumed to be $2.1 \mathrm{wt} \%$ ${ }^{235} \mathrm{U}$. In this CSER, all the fuel is assumed to be $1.25 \mathrm{wt} \%{ }^{235} \mathrm{U}$. The small amount of $2.1 \mathrm{wt} \%$ ${ }^{235} \mathrm{U}$ fuel that could potentially be in the MCO, corrode, and be discharged to the PWC system would not measurably affect the reactivity. Also, the average enrichment of the uranium discharged to the PWC system from the MCO dedicated to SPR fuel will be much less than the assumed $1.25 \mathrm{wt} \%{ }^{235} \mathrm{U}$.

Plutonium isotopes are formed in the N Reactor and SPR fuel during reactor operation. Most of the oxidized fuel particulate (mostly uranium and plutonium) suspended in the MCO water will be from the surfaces of the fuel, where the burnup peaks. At the surfaces of $1.25 \mathrm{wt} \%$ enriched uranium fuel, the buildup rate of plutonium is less than the depletion rate of fissile uranium isotopes (Schwinkendorf 1997). Because the reactivity of ${ }^{235} \mathrm{U}$ and ${ }^{239} \mathrm{Pu}$ is roughly equivalent (HNF-PRO-537) and negative-worth fission products also build up, fresh $1.25 \mathrm{wt} \%$ enriched $N$ Reactor fuel is neutronically more reactive for criticality considerations (higher $\mathbf{k}_{\omega}$ ) than spent $N$ Reactor fuel containing plutonium isotopes and lower ${ }^{235} \mathrm{U}$ levels from burnup. On the other hand, in uranium fuel with an enrichment of $0.95 \mathrm{wt} \%{ }^{235} \mathrm{U}$ or less, plutonium can build up faster at the surfaces than ${ }^{235} \mathrm{U}$ burns out (Schwinkendorf 1997). However, the fissile concentration $\left({ }^{235} \mathrm{U}\right.$ plus ${ }^{239} \mathrm{Pu}$ in total heavy metal) remains below $1.0 \mathrm{wt} \%$ for all burnup levels (Schwinkendorf 1997). 
Thus, assuming that plutonium does not leach out of the fuel and oxidize at a significantly higher rate than uranium, it is conservative to base the criticality analyses on the composition of fresh $1.25 \mathrm{wt} \%{ }^{235} \mathrm{U}$ enriched fuel. There is good evidence indicating this is a valid assumption. Ratios of uranium to plutonium in sludge samples from the $\mathrm{K}$ Basin sandfilter backwash pit averaged 400 to 1 (Erickson 1994). The actinide concentrations in these samples should be indicative of those on corroded fuel surfaces, although some of the sample material is undoubtedly from broken fuel. The average ratio of uranium to plutonium in $\mathrm{N}$ Reactor fuel stored in the $\mathrm{K}$ Basins is estimated to be about 510 to 1 from the data in HNF-SD-SNF-TI-015, Spent Nuclear Fuel Project Technical Databook (Reilly 1998). Using the ratio of 510 to 400 , or 1.28, provides an indication of the buildup and corrosion rate of plutonium on fuel surfaces relative to the average fuel buildup rate of plutonium. From data computed in HNF-SD-SNF-CSER-005 (Schwinkendorf 1997), the rate of plutonium buildup near the surfaces of $N$ Reactor fuel is estimated to be a factor of about 1.6 higher than the average plutonium buildup in $N$ Reactor fuel. Comparing the ratios inferred from measured and computed data does not suggest that plutonium leaches out and corrodes at a faster rate than uranium, because the samples contained less plutonium (i.e., a higher uranium-to-plutonium ratio) than would be predicted from the computed data. The contribution of broken fuel to the sludge samples is probably part of the reason the ratio inferred from measured data (1.28) is less than the computed result (1.6).

Analysis of the effect on $\mathrm{k}_{\text {eff }}$ of fission product decay over a long period of time (e.g., 100 years or more), also described in HNF-SD-SNF-CSER-005 (Schwinkendorf 1997), provides further justification for use of fresh fuel characteristics. As a result, the isotopic content of unexposed fuel with a uranium enrichment of $1.25 \mathrm{wt} \%{ }^{235} \mathrm{U}$, used in these analyses, is the most limiting composition from a criticality standpoint. 
Figure 2-1. Cold Vacuum Drying Facility Process Water Conditioning System Flow Diagram.

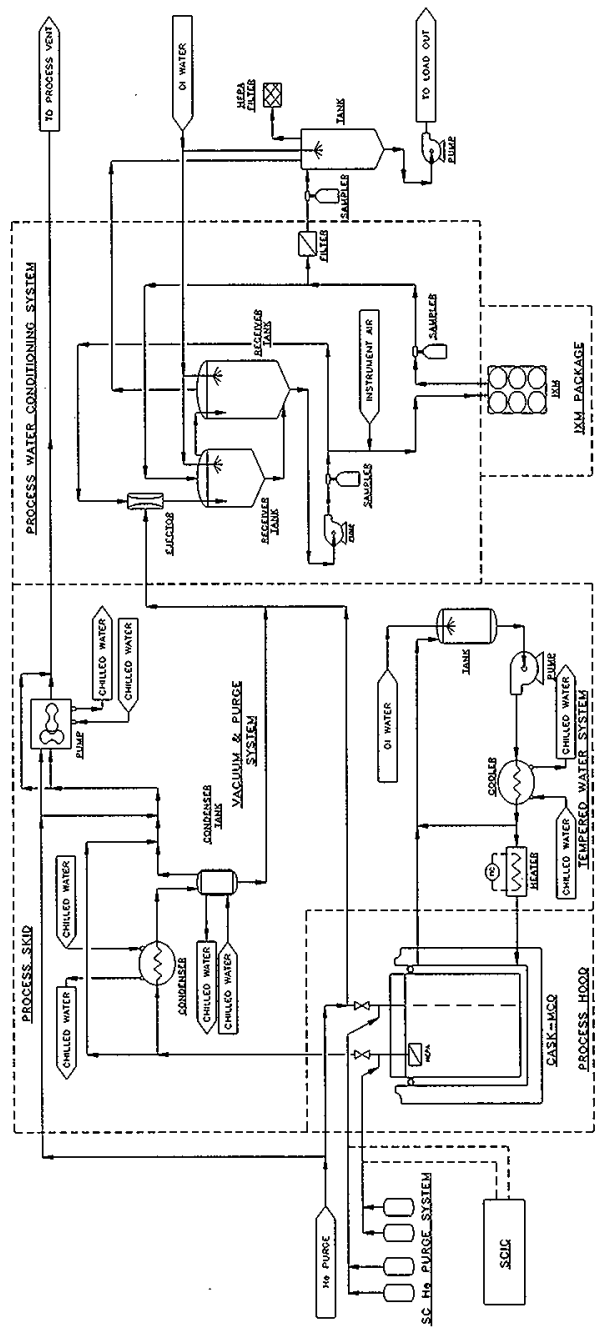


HNF-SD-SNF-CSER-006 REV 2

\subsection{REQUIREMENTS AND EXEMPTIONS}

This analysis must meet the requirements of HNF-PRO-539, Criticality Safety Evaluations. No exemptions from these requirements apply to this evaluation.

\subsection{CRITICALITY SAFETY CRITERION FOR REACTIVITY CALCULATIONS}

The criticality safety criterion for operations at the CVDF requires that the effective neutron multiplication constant $\left(\mathrm{k}_{\mathrm{eff}}\right)$ of a fissile material configuration be less than 0.95 (Garvin 1998). Thus, for this CSER a $\mathrm{k}_{\mathrm{eff}}$ limit of 0.95 is used to meet the requirements of HNF-PRO-537, Criticality Safety Control of Fissionable Material, including the double contingency principle. The double contingency principle requires that process designs incorporate sufficient factors of safety that at least two unlikely, independent, and concurrent or sequential changes in process conditions occur before a criticality accident is possible. The analyses in this CSER must demonstrate compliance with the double contingency principle by showing that any expected configuration and concentration of fissionable material, and any single contingency, will not exceed $\mathrm{a}_{\mathrm{eff}}$ of 0.95 . Contingencies include a spill caused by an MCO drain line break, the rupture of a vessel or a receiver tank overflow, filter failure, IXM failure, and a design basis earthquake.

\subsection{APPLICATION OF THE CRITICALITY SAFETY CRITERION}

Fissile material configurations must be analyzed to demonstrate that $\mathrm{k}_{\mathrm{eff}}$ will be less than the established limit of 0.95 . The criticality safety criterion used to judge the acceptability of a calculated $\mathrm{k}_{\mathrm{eff}}$ for a fissionable material configuration must account for the bias inherent in the computer code and nuclear cross sections used, any uncertainties in the physical problem being analyzed, and the uncertainties in both the bias determination (the experimental basis) and the calculational method. In general, this may be stated as follows:

$$
\mathrm{k}_{\mathrm{cff}}=\mathrm{k}_{\mathrm{calc}}-\Delta \mathrm{k}_{\mathrm{bias}}+\left(\sigma_{\mathrm{b}}^{2}+\sigma_{\mathrm{c}}^{2}+\sigma_{\mathrm{d}}^{2}+\sigma_{\mathrm{c}}^{2}+\sigma_{\mathrm{T}}{ }^{2}\right)^{1 / 2} \leq \mathrm{k}_{\text {limit }}
$$

where

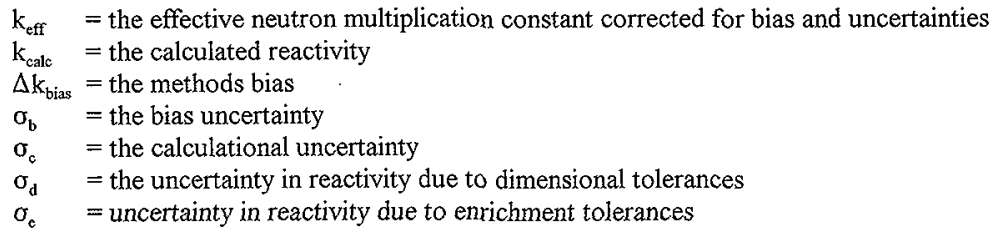


$\sigma_{\mathrm{T}} \quad=$ uncertainty in reactivity due to temperature variations

$\mathrm{k}_{\mathrm{limit}}=$ the established limit on $\mathrm{k}_{\text {eff }}, 0.95$ for this analysis.

For calculations involving solutions in the PWC system, the maximum enrichment of $1.25 \mathrm{wt} \%$ ${ }^{235} \mathrm{U}$ is used, and temperature variations and dimensional tolerances are either directly accounted for or are assumed to be insignificant. Thus, $\sigma_{d}, \sigma_{c}$, and $\sigma_{\mathrm{T}}$ are set to zero.

The criticality calculations in this study were performed using the MCNP computer code, version 4A (Breismeister 1993, Carter 1996). The calculated $\mathrm{k}_{\text {eff }}$ must be at the $95 \%$ confidence level. In a previous study (Schmittroth 1996), the following expression for the upper bound $\mathrm{k}_{\mathrm{eff}}$ at the $95 \%$ confidence level was developed for analysis of low-enrichment uranium systems using MCNP 4A with ENDF/B-V cross section data:

$$
\mathrm{k}_{\mathrm{eff}}=\mathrm{k}_{\mathrm{calc}}-\Delta \mathrm{k}_{\mathrm{bias}}+\left[\left(2 \sigma_{\mathrm{b}}\right)^{2}+\left(1.645 \sigma_{\mathrm{c}}\right)^{2}\right]^{1 / 2} \leq \mathrm{k}_{\text {limit }}
$$

where

$$
\begin{aligned}
& \Delta \mathrm{k}_{\text {bias }}=-0.0004 \\
& \sigma_{\mathrm{b}}=0.005 \\
& \sigma_{\mathrm{c}} \quad \text { varies with each calculation. }
\end{aligned}
$$

Inserting the values for $\mathrm{k}_{\text {limit, }}, \Delta \mathrm{k}_{\mathrm{bias}}$ and $\sigma_{\mathrm{b}}$, into the equation above gives the following expression:

$$
\mathrm{k}_{\mathrm{eff}}=\mathrm{k}_{\mathrm{calc}}+0.0004+\left[0.0001+\left(1.645 \sigma_{\mathrm{c}}\right)^{2}\right]^{1 / 2} \leq 0.95
$$


HNF-SD-SNF-CSER-006 REV 2

\subsection{METHOD OF ANALYSIS AND RESULTS}

\subsection{QUALIFICATION OF THE ANALYSIS METHOD}

The MCNP Monte Carlo computer code, version 4A (Breismeister 1993, Carter 1996) was used for the criticality calculations performed in support of this CSER. This section discusses the qualification of the analysis method used in this CSER and in HNF-SD-SNF-CSER-009, Calculation of $1.25 \%{ }^{235} \mathrm{U}$ Enriched $\mathrm{UO}_{2}$ Solution Safe Slab, Safe Cylinder Diameter, Minimum Safe Mass, and Ion Exchange Module for the CVDF (Nelson 1998), in which many supporting calculations are reported.

MCNP, which was developed at Los Alamos National Laboratory, is used world-wide and has been extensively tested with its ENDF/B-V based cross sections. The code development group that maintains MCNP at the Los Alamos National Laboratory has a set of 25 calculational benchmarks that extensively test various options within the code. These benchmarks are used to confirm that new versions of the code give exactly the same answer as older versions and that. executables for users at other sites give exactly the same answer. Verification that the version of MCNP on computers used for calculations reported in this CSER gives correct results for the 25 benchmark cases has been documented (Carter 1996).

Although the logic within MCNP has been checked with the benchmarks and the general reliability of the code with its cross section database also has been compared with numerous experimental measurements, it is important to quantify its performance by comparisons with experiments relevant to the present applications for K Basin fuel. Such a comparison with relevant experiments with low-enrichment uranium has been made to determine the best estimate of the bias in the calculations as well as the uncertainty in the bias (Schmittroth 1996). Values for the calculational bias and uncertainty applied in this CSER were given in Section 3.2.

\subsection{NORMAL OPERATION EVALUATION}

This section discusses the design acceptability of equipment containing fissionabie materials in the CVDF PWC system. A summary of the normal operations and controls on the equipment items is presented in Table 4-1. The off-normal conditions included in Table 4-1 are discussed in Section 5.0 .

In all cases (normal and off-normal), the fuel material in water solution is assumed to be made up of unirradiated uranium, in oxide form $\left(\mathrm{UO}_{2}\right)$, enriched to $1.25 \mathrm{wt} \%{ }^{235} \mathrm{U}$. This composition is limiting from a reactivity standpoint for all solutions, as discussed in Section 2.3 . 
Table 4-1. Normal and Off-Normal Conditions of Cold Vacuum Drying Facility Equipment. (2 sheets)

\begin{tabular}{|c|c|c|c|}
\hline Equipment item & Normal function & Criticality controls ${ }^{*}$ & Accident condition \\
\hline $\begin{array}{l}\text { PWC receiver tanks } \\
\text { ( } 300 \text { gal total volume) }\end{array}$ & $\begin{array}{l}\text { The PWC receiver tanks } \\
\text { collect water from the MCO } \\
\text { before other processing is } \\
\text { initiated. The tanks meet the } \\
\text { criticality safety criterion for } \\
\text { all credible quantities of } \\
\text { fissionable materials and } \\
\text { water. }\end{array}$ & $\begin{array}{l}\text { 1) Extraction of a quantity } \\
\text { of actinides from an MCO } \\
\text { exceeding the minimum safe } \\
\text { mass }(875 \mathrm{~kg}) \text { is not } \\
\text { credible. } \\
\text { 2) The inner diameter and } \\
\text { spacing of the tanks meet } \\
\text { the critically favorable } \\
\text { dimensions specified in } \\
\text { limit } 2 .\end{array}$ & $\begin{array}{l}\text { No credible accident will } \\
\text { violate controls. }\end{array}$ \\
\hline $\begin{array}{l}\text { IXM with six ion } \\
\text { exchange columns }\end{array}$ & $\begin{array}{l}\text { The IXM removes fissionable } \\
\text { materials from MCO water. } \\
\text { This module meets the } \\
\text { criticality safety criterion for } \\
\text { all credible quantities of } \\
\text { fissionable materials and } \\
\text { water. }\end{array}$ & $\begin{array}{l}\text { 1) Buildup of fissionable } \\
\text { material in the IXM } \\
\text { exceeding the minimum safe } \\
\text { mass is not credible. } \\
\text { 2) Diameter, wall thickness, } \\
\text { and length of ion vessels do } \\
\text { not exceed specifications of } \\
\text { limit } 4 \text {. }\end{array}$ & $\begin{array}{l}\text { No credible accident will } \\
\text { violate controls. }\end{array}$ \\
\hline $\begin{array}{l}\text { Filter located } \\
\text { downstream of IXM }\end{array}$ & $\begin{array}{l}\text { The filter removes particles of } \\
\mathrm{UO}_{2} \text { from } \mathrm{MCO} \text { water. The } \\
\text { filter vessel meets the } \\
\text { criticality safety criterion for } \\
\text { all credible quantities of } \\
\text { fissionable materials and } \\
\text { water. }\end{array}$ & $\begin{array}{l}\text { 1) Buildup of fissionable } \\
\text { material in the filter } \\
\text { exceeding the minimum safe } \\
\text { mass is not credible. } \\
\text { 2) Inner diameter is less } \\
\text { than the safe diameter } \\
\text { specified in limit } 3 \text {. }\end{array}$ & $\begin{array}{l}\text { No oredible accident will } \\
\text { violate controls. }\end{array}$ \\
\hline Storage tank & $\begin{array}{l}\text { The storage tank collects } \\
\text { filtered and demineralized } \\
\text { processed water from MCO. }\end{array}$ & $\begin{array}{l}\text { 1) Mass of actinides in the } \\
\text { tank and other PWC } \\
\text { components will not exceed } \\
\text { the } 875 \mathrm{~kg} \text { specified in } \\
\text { limit } 1 \text { because of the } \\
\text { limited quantity extracted } \\
\text { from each } \mathrm{MCO}(13.2 \mathrm{~kg} \\
\text { maximum), the high } \\
\text { efficiency of the IXM and } \\
\text { filter, and the sampling and } \\
\text { monitoring program. } \\
\text { 2) Radiation levels in the } \\
\text { PWC room would become } \\
\text { unacceptable long before the } \\
\text { criticality limits are reached. }\end{array}$ & $\begin{array}{l}\text { No credible scenario would } \\
\text { result in reaching the } \\
\text { criticality limit of } 875 \mathrm{~kg} \text { of } \\
\text { actinides being allowed to } \\
\text { collect in the tank. The } \\
\text { IXM, filter, and tank } \\
\text { monitoring and water } \\
\text { quality program would } \\
\text { have to repeatedly fail over } \\
\text { an extended period of time, } \\
\text { and high radiation levels } \\
\text { that would be detected by } \\
\text { both area radiation } \\
\text { monitors and RCTs would } \\
\text { have to be repeatedly } \\
\text { ignored. }\end{array}$ \\
\hline
\end{tabular}


Table 4-1. Normal and Off-Normal Conditions of Cold Vacuum Drying Facility Equipment. (2 sheets)

\begin{tabular}{|c|c|c|c|}
\hline Equipment item & Normal function & Criticality controls & Accident condition \\
\hline $\begin{array}{l}\text { Piping, condensation } \\
\text { collectors, and small } \\
\text { collection tank in the } \\
\text { vacuum and purge } \\
\text { system. }\end{array}$ & $\begin{array}{l}\text { The piping, condensation } \\
\text { collectors, and small collection } \\
\text { tank collect and store residual } \\
\text { moisture from the vacuum } \\
\text { drying and helium purge } \\
\text { operations that dry the furel in } \\
\text { each MCO. }\end{array}$ & $\begin{array}{l}\text { 1) Collection of significant } \\
\text { quantities of fissionable } \\
\text { material in the vacuum and } \\
\text { purge system is not credible. } \\
\text { 2) Inner diameter of all } \\
\text { components is less than the } \\
\text { safe diameter specified in } \\
\text { limit } 3 \text {. }\end{array}$ & $\begin{array}{l}\text { No credible accident will } \\
\text { violate controls. }\end{array}$ \\
\hline $\begin{array}{l}\text { Floor area in PWC room } \\
\text { in region of potential } \\
\text { spills of } \mathrm{MCO} \text { water }\end{array}$ & $\begin{array}{l}\text { The floor contains spills from } \\
\text { receiver tanks and associated } \\
\text { equipment or tuptures or leaks } \\
\text { in piping and other MCO } \\
\text { water containers. }\end{array}$ & $\begin{array}{l}\text { The mass of actinides in the } \\
\text { system cannot credibly } \\
\text { exceed the minimum safe } \\
\text { mass of } 875 \mathrm{~kg} \text { specified in } \\
\text { limit } 1 \text {, let alone the much } \\
\text { higher critical mass for a } \\
\text { slab on the PWC room floor. }\end{array}$ & $\begin{array}{l}\text { No credible accident can } \\
\text { lead to a criticality on the } \\
\text { PWC room floor, even a } \\
\text { design basis earthquake or } \\
\text { other common cause failure } \\
\text { that results in all MCO } \\
\text { water and associated } \\
\text { fissionable material in the } \\
\text { PWC room being spilled to } \\
\text { the floor. }\end{array}$ \\
\hline $\begin{array}{l}\text { Transported fissionable } \\
\text { materials }\end{array}$ & $\begin{array}{l}\text { Samples or other fissionable } \\
\text { materials are transported by } \\
\text { personnel. }\end{array}$ & $\begin{array}{l}\text { 1) Accumulation of } \\
\text { actinides in the PWC room, } \\
\text { including maximum } \\
\text { quantities that would be } \\
\text { transported by personnel, } \\
\text { cannot credibly exceed the } \\
\text { minimum safe mass } \\
\text { specified in limit } 1 . \\
\text { 2) Concrete walls } 12 \text { in. } \\
\text { thick isolate the PWC room } \\
\text { from fissionable materials } \\
\text { outside the room. }\end{array}$ & $\begin{array}{l}\text { No credible accident will } \\
\text { violate the mass limit. }\end{array}$ \\
\hline
\end{tabular}

*The limits $(1,2,3$, and 4$)$ listed are defined in Section 1.2.1.

IXM $=$ ion exchange module.

$\mathrm{MCO}=$ multi-canister overpack.

$\mathrm{PWC}=$ process water conditioning.

$\mathrm{RCT}=$ radiological control technician. 


\subsubsection{Process Water Conditioning Receiver Tanks}

The PWC receiver tank collects water from the MCO. This water is not sampled for fissionable material content before it is transferred to the receiver tanks. Therefore as a prudent measure, the tanks are designed to be geometrically safe for all possible fissionable material concentrations in incoming water (see limit 2 in Section 1.2.1) even though extraction of a minimum critical mass from an $\mathrm{MCO}$ is not considered possible. The volume of the tanks is adequate to hold the liquid contents of an $\mathrm{MCO}$, the volume of the clean water used to flush the process piping after draining, and the water removed from the $\mathrm{MCO}$ during the vacuum drying process. Before receiving water from an $\mathrm{MCO}$, the PWC receiver tanks are drained of most water. A small amount remains to prime the water jet ejector. Instrumentation is in place to stop tank filling to prevent an overflow to the storage tank. These controls are not required for criticality safety.

\subsubsection{Process Water Conditioning Ion Exchange Module}

A PWC IXM removes almost all of the ionic fissionable materials from the water as the water is being processed. The accumulation and concentration of fissionable materials in the incoming water are not controlled. Therefore, the geometry of the IXIM is controlled in accordance with limit 4 as a prudent measure even though accumulation of a minimum critical mass in the IXM is not considered possible.

\subsubsection{Piping, Pumps, and Filter}

All piping, pumps, and the filter installed in the PWC system are designed to have critically favorable geometries complying with limit 3 . Again, this measure is not essential to criticality safety because accumulation of a minimum critical mass in these components is not considered possible.

\subsubsection{Storage Tank}

The 5,000-gal storage tank receives filtered and demineralized process water from the receiver tanks. Only a very small fraction of the uranium oxide (less than 0.0001 ) and other fissionable materials is expected to penetrate the filter and IXM because of the high efficiency of these components. Even if the estimated maximum of $13.2 \mathrm{~kg}$ of actinides were extracted from each of the $440 \mathrm{MCOs}$, a total of only about $0.6 \mathrm{~kg}$, less than $1 \%$ of the minimum safe mass, is expected to be transferred to the storage tank if the IXM and filter function properly.

Part of the fissionable material that penetrates the filter and IXM remains soluble and enters the storage tank as trace contaminants. The remainder of the fissionable materials settles and forms deposits in the tank. A significant buildup of deposits is not anticipated, but operation of the PWC system requires prevention of fissionable material accumulation in the storage tank to 
HNF-SD-SNF-CSER-006 REV 2

ensure that radiation levels in the PWC room remain at an acceptable level. If fissionable material is allowed to build up in the tank, radiation levels in the PWC room will become excessive long before criticality limits are challenged.

\subsubsection{Liquid Retention Basin}

A liquid retention basin is located on the bottom of the PWC room skid and on the bottom of the process equipment skid in each process bay. The basin collects any leakage or spillage from the hardware on the skids. The maximum depth of the basins, about 1.25 in., is much less than the maximum safe slab depth of $10.5 \mathrm{in}$. (Nelson 1998), so the basin geometry is critically favorable.

\subsubsection{Vacuum and Purge System}

The vacuum and purge syster, which includes piping, condensation collectors, and a small, 7-gal collection tank, is connected to the top of the MCO through the top of the short process tube. This tube is not long enough to reach into the basket region of the MCO. In addition, there is a high-efficiency particulate air filter in the top of the MCO in line with the tube. Thus, only trace quantities of fissionable material will enter the system. Also, the geometry of the system components is critically favorable, complying with limit 3. 
HNF-SD-SNF-CSER-006 REV 2

This page intentionally left blank. 
HNF-SD-SNF-CSER-006 REV 2

\subsection{CONTINGENCY ANALYSIS}

This section discusses the credible contingencies that may occur in the equipment at the CVDF. The limits, controls, and accident conditions are listed in Table 4-1. The contingencies analyzed were based on the assumed maximum of $13.2 \mathrm{~kg}$ actinides transferred from each MCO to the PWC system. This is a very conservative assumption because, on average, less than $100 \mathrm{~g}$ is expected to be transferred (see Table 2-1).

\subsection{POTENTLAL ERROR OR FAILURE SITUATIONS}

HNF-PRO-539, Appendix A, identifies "Potential Error/Failure Situations" to help perform criticality safety evaluations and identify areas in which criticality problems may develop. An evaluation of each of the potential errors is discussed below as it applies to the PWC system.

Item 1. Equipment dimension variation due to

- Mechanical disarrangement (e. g., earthquake)

- Effects from accidental pressurization.

Comment: The PWC system equipment has been analyzed for mechanical disarrangement caused by seismic events and heavy load drops. Physical limitations and controls on the mass of fissionable material that can be in the system ensure that even if the equipment catastrophically failed, the amount of fuel actinides concentrated or spilled would be much less than the minimum safe mass of $875 \mathrm{~kg}$. An incredible second independent and concurrent or sequential contingency would have to occur in order to exceed the reactivity limit. Therefore, the double contingency principle is met.

Item 2. Excesses in mass or volume from errors in

- Segregating materials from different enrichments

- Overbatching

- Analysis error.

Comment: HNF-SD-SNF-CSER-010, Criticality Safety Evaluation Report for the K Basin Fuel Retrieval Subproject (Kessler and Peck 1998), defines the requirements for loading MCO baskets in the $\mathrm{K}$ Basins. Analyses in this CSER assume the maximum enrichment of $1.25 \mathrm{wt} \%{ }^{235} \mathrm{U}$ and the estimated maximum value of $13.2 \mathrm{~kg}$ for the mass of uranium and actinide products released from an MCO to the PWC system. Normally, the receiver tanks will contain the water from no more than one $\mathrm{MCO}$, but it is physically possible to drain two MCOs into the receiver tanks. However, if two MCOs, each containing the maximum assumed actinide mass, were discharged to the receiver tanks, there would be only $26.4 \mathrm{~kg}$ total actinide mass, compared with the minimum safe mass limit of $875 \mathrm{~kg}$. Therefore, the geometry control provided by the dimensions of the tanks is not essential to criticality. 
HNF-SD-SNF-CSER-006 REV 2

Item 3. Excess of mass in a non-safe geometry vessel resulting from

- Cross connections

- Unauthorized piping changes

- IXM failures

- Filter failures.

Comment: The maximum quantity of fissionable material allowed to build up in the sediments or to be dissolved or suspended in the water of the storage tank is very small compared with the limit 1 mass of $875 \mathrm{~kg}$. The storage tank can only hold the water from draining and processing 15 to $20 \mathrm{MCO}$. Thus, in the unlikely event that both the fitter and the IXM fail, or they are bypassed, the maximum fissionable mass that could accumulate in the tank before it filled would be $264 \mathrm{~kg}$. Even if this entire mass settled out and was not drained or flushed out, a minimum of 66 maximally loaded MCOs would need to be processed to exceed the minimum safe mass. This would require continuous failure of both the IXM and the fitter over several months and failure to detect or respond to high radiation levels in the PWC room. In summary, a criticality in the storage tank is incredible because it requires a whole series of very unlikely and independent events.

Item 4. Changes in geometry resulting from

- Spilling or leakage

- Mechanical compacting.

Comment: The process water containing fissionable materials from an $\mathrm{MCO}$ is first pumped to the PWC receiver tanks. The maximum combined quantity of process water in the receiver tanks is 300 gal when they are filled to capacity. The worst-case spill accident assumes the whole 300 gal of water containing fissionable materials is released from the receiver tanks to the PWC room floor. All the water in other PWC room vessels (the 5,000-gal storage tank, IXM, and filter) is also assumed to be released as the result of a common cause failure, such as a design basis earthquake. Since, as stated earlier, it is incredible to have more than a total of $875 \mathrm{~kg}$ fuel actinides in the PWC system, the assumed maximum spill on the floor cannot go critical even though the water depth on the floor, about 16.6 in., exceeds the safe slab depth of $10.5 \mathrm{in}$. determined in HNF-SD-SNF-CSER-009 (Neison 1998). To get a $\mathrm{k}_{\text {eff }}$ of 0.95 in a 10.5-in. slab requires an optimal concentration of fuel particulate in the water. The total uranium mass necessary to achieve this concentration on the PWC room floor is over $43,000 \mathrm{~kg}$. One MCNP calculation was run with $6,000 \mathrm{~kg}$ of $1.25 \mathrm{wt} \%$ enriched uranium in oxide form homogeneously mixed in a 16.6-in.-high slab on a concrete surface. This case (slb42086) gave a $\mathrm{k}_{\text {eff }}$ of only 0.38 (see Appendix A). Clearly, a criticality due to a spill on the PWC room floor is incredible.

Item 5. Changes in reflection from

- Flooding

- Addition of shielding (dose reduction campaign). 
HNF-SD-SNF-CSER-006 REV 2

Comment: All PWC system operations were analyzed assuming optimal water moderation and reflection.

Item 6. Changes in concentration from

- Precipitation

- Accumulation

- Evaporation.

Comment: There is no chemical change of state and no changes in physical form. The minimum safe mass of $875 \mathrm{~kg}$ uranium was computed for optimal conditions. Accumulation of fissionable material in the storage tank has been evaluated (see item 3).

Item 7. Increased interaction from

- Material in transit

- Spacing error

- Changes in relative positions of units.

Comment: Interactions between the two receiver tanks, the filter, and piping, which are in close proximity ( $<12$ in.), were evaluated (see Section 5.2.1). The receiver tank spacing assumed in most calculations was 6 in. though the design calls for a spacing of almost $10 \mathrm{in}$. Calculations also showed that under optimal conditions, the fissionable material in the piping and filter do not add measurably to the reactivity of the receiver tanks alone. Even if the spacing between these components is not maintained, the total fissionable mass involved will be far less than the minimum safe mass. For this reason, there are no requirements on the transfer of samples within the $\mathrm{PWC}$ room.

Item 8. Changes in moderation from

- Condensation

- Evaporation.

Comment: The criticality analyses for the PWC system operations assumed that the fissionable material was optimally moderated and reflected. Condensation will increase moderation of the material above optimal and lower the $\mathrm{k}_{\mathrm{eff}}$. Evaporation will undermoderate the material and also lower $\mathrm{k}_{\text {eff }}$.

\subsection{REQUIREMENT FOR CRITICALITY INSTRUMENTATION}

This section consists of an evaluation of the need for a criticality alarm system and a criticality detection system in the CVDF PWC room. HNF-PRO-546, Criticality Alarm System, states that neither a criticality alarm system nor criticality detection system is required where the probability of a criticality accident is determined to be less than $1 \times 10^{-6}$ per year. This 
requirement in HNF-PRO-546 is consistent with the national standard (ANSI/ANS-8.3-1997) and with DOE Order 5480.24, Nuclear Criticality Safety. Interpretive guidance on the probability determination (Holten 1993) states: "The use of $10^{-6}$ does not necessarily mean that a PRA [probabilistic risk assessment] has to be performed. Reasonable grounds shall be presented on the basis of commonly accepted engineering judgement."

Section 5.1 evaluated a comprehensive list of potential accident scenarios and concluded in each case that the consequences could not lead to a criticality. Here, the locations in the PWC room where significant quantities of fissionable material could accumulate are identified and evaluated for criticality potential based on the identified accident scenarios. The following sections describe qualitative engineering analyses that conclude that a criticality in the PWC room is incredible (probability less than $10^{-6}$ per year). Thus, a criticality alarm system or criticality detection system is not required in the PWC room.

\subsubsection{Receiver Tanks}

The receiver tanks have a combined volume of 300 gal. Each $\mathrm{MCO}$ will contain about $130 \mathrm{gal}$ of water that will be extracted and transferred to the receiver tanks. Thus, even in the abnormal event that the receiver tank is not emptied and the transfer piping flushed after each $\mathrm{MCO}$, the water from only two MCOs can be contained in the receiver tanks. The maximum actinide mass in the receiver tanks would then be only $26.4 \mathrm{~kg}$, compared to the safe mass limit of $875 \mathrm{~kg}$ actinides. Extraction of the maximum mass of $13.2 \mathrm{~kg}$ actinides from $66 \mathrm{MCOs}$ is required to accumulate $875 \mathrm{~kg}$.

Even if it were possible to accumulate a total mass of $875 \mathrm{~kg}$ of actinides in the receiver tanks and the spacing between the full receiver tanks ( $875 \mathrm{~kg}$ actinides), the filter ( $30 \mathrm{~kg}$ actinides), and piping on the skid were lost, a criticality would not occur. MCNP calculations were made using a model with essentially no spacing between receiver tanks, the filter, and two sections of 2-in. pipe on the skid (cases rt0fp0a and stofp0b in Appendix A). The pipes, which were modeled as running vertically, one next to each tank, contained the same density of uranium in water as the receiver tanks (i.e., $875 \mathrm{~kg}$ in $300 \mathrm{gal}$ ). The only difference between the two cases was the density of the interstitial water around and between the solution containers. The first case had full density water $\left(1 \mathrm{~g} / \mathrm{cm}^{2}\right)$, while the second had the water at $0.2 \mathrm{~g} / \mathrm{cm}^{2}$, a density that was determined to be about optimal for tanks separated by $6 \mathrm{in}$. (Nelson 1998). Both cases gave $\mathrm{k}_{\mathrm{exX}}$ values less than 0.62 . Far more than $875 \mathrm{~kg}$ of actinides in the receiver tanks would be required for a criticality, even with loss of separation control.

Any appreciable collection of fuel material in the receiver tanks will result in high radiation levels in the PWC room. Figure 5-1, for example, shows the dose rates in the PWC room from a $15 \mathrm{~kg}$ inventory of fuel actinides plus associated fission products. The data shown were scaled from the results of an earlier shielding study (Miska and Nelson 1998). Dose rates up to $20 \mathrm{rem} / \mathrm{h}$ near the receiver tanks can be seen in the figure, with dose rates exceeding $100 \mathrm{mrem} / \mathrm{h}$ at most unshielded locations in the room. Dose rates in the adjacent process bay were estimated to be as 
HNF-SD-SNF-CSER-006 REV 2

high as $100 \mathrm{mrem} / \mathrm{h}$. Clearly, these radiation levels would not go undetected for long by area radiation monitors and radiological control technicians (RCTs).

MCOs are to be processed through the CVDF on the order of one per day. Thus, a minimum of around 2 months would be required to accumulate a critical mass. Failure of area radiation monitors and administrative procedures for monitoring radiation levels over this period of time is inconceivable. Clearly, the probability of a criticality in the receiver tanks is essentially zero - certainly orders of magnitude less than $10^{-6}$ per year.

\subsubsection{Ion Exchange Module}

The IXM has the same design as IXMs currently in service at the K Basins. They have a critically favorable geometry (Nelson 1998), but like the receiver tanks, they are not being procured as safety-class equipment. Thus, their structural failure cannot be ruled out in an unusual event such as a design basis earthquake. However, it is improbable that a structural failure would lead to a more optimal geometry that is sufficient to support a critical reaction. The probability of this occurring is very low.

Operating procedures at the CVDF call for limiting the actinide accumulation in the IXM to less than $2 \mathrm{~kg}$ so the vessels will not have to be disposed of as transuranic waste. As described in the previous section, these procedures would have to be neglected over at least a 2-month period before a critical mass could accumulate under the worst-case scenario. This scenario assumes that one $\mathrm{MCO}$ is processed per day, with the maximum of $13.2 \mathrm{~kg}$ of actinides extracted from each, and the efficiency of the IXM remains high. Because each IXM is shielded by concrete, dose rates in the PWC room would be only somewhat elevated. Based on calculations done as part of a shielding analysis (Miska and Nelson 1998), a 290-kg inventory of fuel actinides (one-third of the minimum safe mass) plus associated fission products would result in contact dose rates close to $90 \mathrm{mrem} / \mathrm{h}$, with dose rate $6 \mathrm{ft}$ away around $10 \mathrm{mrem} / \mathrm{h}$.

Thus, a criticality in the IXM would require, at a minimum, both of the following failures to occur:

1. Major structural failure of the IXM resulting in a sufficiently optimal geometry (there is a very low probability that an earthquake or explosion would do this)

2. Repeated failure over at least 2 months by operations personnel to monitor the buildup of actinides in an IXM.

The probability of these two highly unlikely events occurring in the same time frame is the product of the probabilities of each failure. This product is certainly less than $10^{-6}$ per year. 


\subsubsection{Process Water Conditioning Filter}

The PWC filter has a critically favorable geometry, first because its diameter ( $6.3 \mathrm{in}$.) is much less than the minimum safe diameter of 23.5 in. (Nelson 1998), and second because its volume $(3.1 \mathrm{gal})$ is too small to support a critical reaction. From data reported in HNF-SD-SNF-CSER-009 (Nelson 1998), the minimum critical volume for an optimized homogeneous mixture of $\mathrm{UO}_{2}$ and water with the uranium enriched to $1.25 \mathrm{wt} \%{ }^{235} \mathrm{U}$ was computed to be 74 gal. Thus, a criticality in the filter tank is impossible with $1.25 \mathrm{wt} \%$ enriched $\mathrm{UO}_{2}$ in water, even for an optimized worst-case loading.

Any large buildup of fuel material on the filter will result in high dose rates. For example, an unshielded filter loaded with $15 \mathrm{~kg}$ of fuel actinides and associated fission products would result in dose rates in the PWC room higher than seen in Figure 5-1. Planned shielding around the filter would significantly reduce the dose rates, but they would still be quite high. With $4 \mathrm{in}$. of steel shielding around the filter and a $15-\mathrm{kg}$ loading, dose rates would still be about $3 \%$ of those shown in Figure $5-1$ ( $3 \mathrm{mrem} / \mathrm{h}$ to $700 \mathrm{mrem} / \mathrm{h})$.

\subsubsection{Storage Tank}

The 5,000-gal storage tank, unlike the PWC room components described above, does not have a critically favorable design. However, under normal conditions, an insignificant quantity of . fissionable material will reach the storage tank because of the high efficiency of the IXM and filter, as discussed in Section 4.2.4. Also, a significant buildup of fuel actinides and fission. products in the tank will result in high radiation levels in the PWC room. Figure 5-2 shows the dose rates expected in the PWC room from $200 \mathrm{~kg}$ of fuel actinides and associated fission products. This quantity, which is less than a quarter of the minimum safe mass of $875 \mathrm{~kg}$, results in dose rate up to $10 \mathrm{rem} / \mathrm{h}$ in the PWC room and over $100 \mathrm{mrem} / \mathrm{h}$ at all unshielded locations in . the room. Computed dose rates at the entry stairway at the west end of the room are about $5 \mathrm{rem} / \mathrm{h}$.

Only two conceivable scenarios could lead to an accumulation of more than the minimum safe mass in the storage tank. These scenarios are developed below.

In the first scenario, all of the following failures must occur concurrently or sequentially.

1. Both the IXM and filter fail undetected while at least $66 \mathrm{MCO}$ are being processed.

2. Area radiation monitors fail continuously or are ignored over a period of at least 2 months.

3. RCTs repeatedly fail to detect or report high radiation readings during the routine surveys that are required by procedure. 
A significant fraction of the fissionable material must settle to the bottom of the tank and remain there after the tank is emptied and flushed. To be conservative, it is assumed that all of the fuel particulate that enters the tank stays there. Thus, the probability of a criticality under this scenario is the product of the probabilities of the three highly improbable failures described. This product is certainly much less than $10^{-6}$ per year.

In the second scenario, the receiver tanks overflow into the storage tank because either the tanks are not drained and flushed between MCOs or the demineralized water used to flush the transfer piping is left running, resulting in the receiver tanks filling up before the MCO is drained. In either case, the majority of the fuel material is postulated to be associated with the overflow water that drains to the storage tank, bypassing the IXM and filter (see Figure 2-1). For a criticality to occur under this scenario, all the following failures must all occur.

1. The postulated errors that allow the receiver tanks to overflow must happen while at least $66 \mathrm{MCOs}$ are being processed.

2. Area radiation monitors fail continuously or are ignored over a period of at least 2 months.

3. RCTs repeatedly fail to detect or report high radiation readings during routine surveys.

As before, to be conservative it is assumed that all of the fuel particulate that enters the tank stays there. The probability of a criticality under this scenario is judged to be much lower than that for the first scenario, so it is certainly much less than $10^{-6}$ per year.

\subsubsection{Other Components}

A criticality in other PWC system components, including pumps, piping, the vacuum and purge system, and the liquid retention basin on the skid, is inconceivable because of the geometry or volume of the components involved (described in Sections 4.2.3, 4.2.5 and 4.2.6). The margin of safety with these components, as with the filter (see Section 5.2.3), is so large that no accident could cause a geometry change sufficient to make a criticality plausible.

\subsubsection{Worst-Case Spill on Process Water Conditioning Room Floor}

There are no low points or sumps in the PWC room where fissionable material could collect after a spill. The quantity of fissionable material required to form a critical mass on the flat PWC room floor is incredibly large, as described in Section 5.1 under item 4. The only scenario in which a criticality could be achieved is one in which the actinide inventory in the PWC room exceeds $875 \mathrm{~kg}$ when a catastrophe occurs, causing this mass to spill onto the floor and the floor to be broken up in such a way that an optimal pool of solution could form. Both events (the high inventory and the disruptive earthquake or explosion) are highly unlikely. The product of their probabilities is certainly much less than $10^{-6}$ per year. 
Figure 5-1. Cold Vacuum Drying Facility Process Water Conditioning Room Dose Rates at 90 Centimeters Elevation from 15 Kilograms of Uranium in Receiver Tanks.

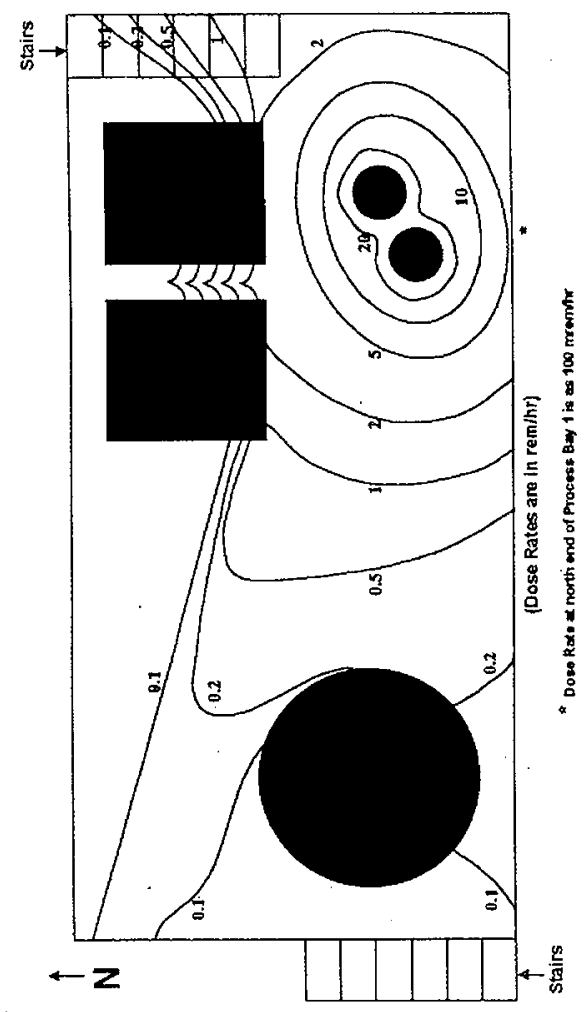


Figure 5-2. Cold Vacuum Drying Facility Process Water Conditioning Room Dose Rates at 90 Centimeters Elevation from 15 Kilograms of Uranium in a 5,000-Gallon Tank.

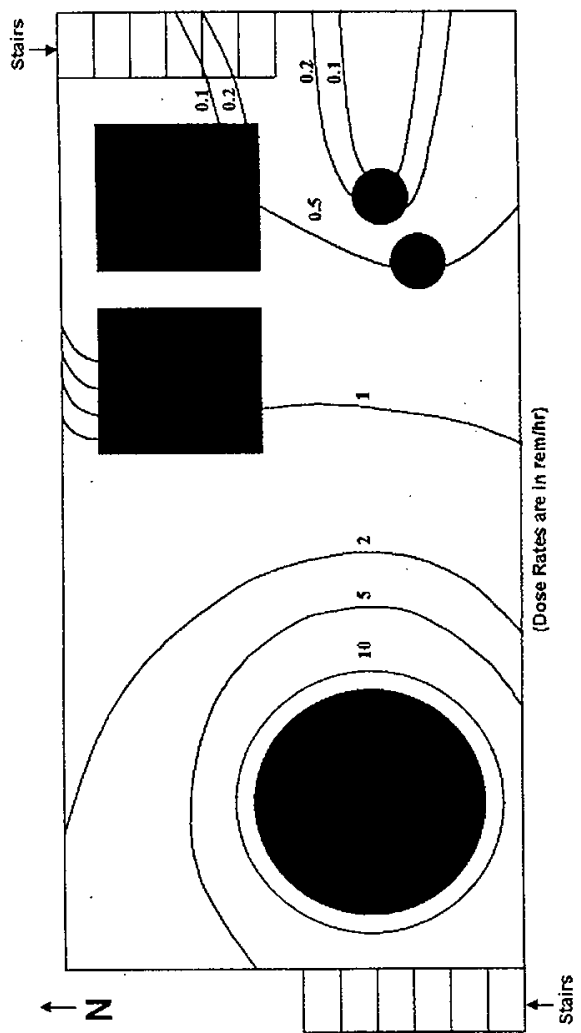


HNF-SD-SNF-CSER-006 REV 2

This page intentionally left blank. 


\subsection{PEER REVIEW}

Document Reviewed: HNF-SD-SNF-CSER-006, Revision 2, Criticality Safety Evaluation Report for the Cold Vacuum Drying Facility's Process Water Conditioning System

Scope of Review: $\quad$ Entire document

Yes No NA

[X] [ ] [ ] * Previous reviews complete and cover analysis, up to scope of this review, with no gaps.

[X] [ ] [ ] Problem completely defined.

[X] [ ] [ ] Accident scenarios developed in a clear and logical manner.

[X] [ ] [ ] Necessary assumptions explicitly stated and supported.

[][]$[\mathrm{X}]$

[]$[$ [ $][X]$

$[\mathrm{X}][][\mathrm{C}$

Computer codes and data files documented.

Data used in calculations explicitly stated in document.

[ ] [ ] $[\mathrm{X}]$

[ ] [ ] $[\mathrm{X}]$

[ ] [ ] $[\mathrm{X}]$

$[1][][\mathrm{X}]$

Data checked for consistency with original source information as applicable.

Mathematical derivations checked including dimensional consistency of results.

[ ] $[\mathrm{J}[\mathrm{X}]$

$\left[\begin{array}{lll}{[} & {[}\end{array}\right]$

Models appropriate and used within range of validity or use outside range of established validity justified.

Hand calculations checked for errors. Spreadsheet results should be treated exactly the same as hand calculations.

Software input correct and consistent with document reviewed.

Software output consistent with input and with results reported in document reviewed.

Limits/criteria/guidelines applied to analysis results are appropriate and referenced. Limits/criteria/guidelines checked against references.

[ ] [ ] [X] Safety margins consistent with good engineering practices.

$[\mathrm{X}][\mathrm{C}[\mathrm{C}$

$[\mathrm{X}][\mathrm{l}][]$

Conclusions consistent with analytical results and applicable limits.

$[\mathrm{X}][\mathrm{]}[\mathrm{]}$

$[\mathrm{X}] \quad[]^{*}$

Results and conclusions address all points required in the problem statement. Format consistent with appropriate NRC Regulatory Guide or other standards Review calculations, comments, and/or notes are attached.

\section{[X] [ ] [ ] Document approved.}

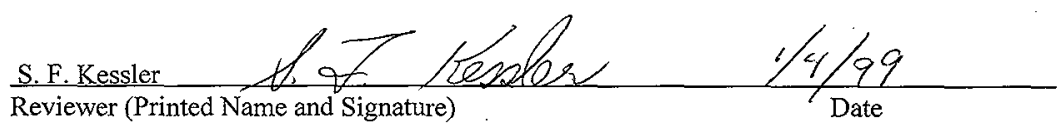

* Any calculations, comments, or notes generated as part of this review should be signed, dated and attached to this checklist. Such material should be labeled and recorded in such a manner as to be intelligible to a technically qualified third party. 


\section{HNF-SD-SNF-CSER-006 REV 2}

The purpose of this revision is to incorporate revised data from revision 1 of HNF-SD-SNFCSER-009, Calculation of $1.25 \%{ }^{235} \mathrm{U}$ Enriched $\mathrm{UO}_{2}$ Solution Safe Slab, Safe Cylinder Diameter, and Ion Exchange Module for the CVDF, and to evaluate the need for a criticality alarm or detection system. Other editorial changes were made to clarify the document and to incorporate comments from the operations reviewers. 


\subsection{REFERENCES}

ANSI/ANS-8.3-1997, Criticality Accident Alarm System, American Nuclear Society, La Grange Park, Illinois.

Arora, S., 1995, Specification for Ion Exchange Modules, IXM, WHC-S-0142, Rev. 1, Westinghouse Hanford Company, Richland, Washington.

Breismeister, J. F., Editor, 1993, MCNP--A General Monte Carlo Code N-Particle Transport Code, Version 4A, LA-12625, Los Alamos National Laboratory, Los Alamos, New Mexico.

Carter, L. L., 1996, Cerification of MCNP Version 4A for WHC Computer Platforms, WHC-SD-MP-SWD-30001, Rev. 8, Westinghouse Hanford Company, Richland, Washington.

Crowe, R. D., S. D. Kopelic, M. G. Piepho, P. D. Rittmann, D. L. Scott, and W. T. Watson, 1998, Cold Vacuum Drying Facility Design Basis Accident Analysis Documentation, HNF-2770, Rev. 1, Fluor Daniel Hanford, Incorporated, Richland, Washington.

DOE Order 5480.24, Nuclear Criticality Safety, U.S. Department of Energy, Washington, D.C.

Erickson, D. G., 1994, Criticality Safety Evaluation Report for the $100 \mathrm{KE}$ Basin Sandfilter Backwash Pit, WHC-SD-NR-CSER-014, Rev. 1, Westinghouse Hanford Company, Richland, Washington.

Garvin, L. J., 1998, Spent Nuclear Fuel Project Path Forward, Additional NRC Requirements, HNF-SD-SNF-DB-003, Rev. 4, Fluor Daniel Hanford, Incorporated, Richland, Washington.

HNF-PRO-537, Criticality Safety Control of Fissionable Material, Fluor Daniel Hanford, Incorporated, Richland, Washington.

HNF-PRO-539, Criticality Safety Evaluations, Fluor Daniel Hanford, Incorporated, Richland, Washington.

HNF-PRO-546, Criticality Alarm Systems, Fluor Daniel Hanford, Incorporated, Richland, Washington.

Holten, R. A., 1993, Interpretive Guidance for DOE 5480.24, Nuclear Criticality Safety (Letter 9305261 to General Manger, Kaiser Engineers Hanford Company; Director, Pacific Northwest Laboratory; President, Westinghouse Hanford Company; July 20), Quality, Safety and Health Programs Division, U.S. Department of Energy, Richland Operations Office, Richland, Washington. 
Kessler, S. F., and S. H. Peck, 1998, Criticality Safety Evaluation Report for the K Basin Fuel Retrieval Subproject, HNF-SD-SNF-CSER-010, Rev. 0, Fluor Daniel Hanford, Incorporated, Richland, Washington.

Miska, C. R., and J. V. Nelson, 1998, Shielding Analysis for the Cold Vacuum Drying Facility Drying Project, HNF-2850, Rev. 0, Fluor Daniel Hanford, Incorporated, Richland, Washington.

Nelson, J. V., 1998, Calculation of 1.25\% ${ }^{235}$ U Enriched $\mathrm{UO}_{2}$ Solution Safe Slab, Safe Cylinder Diameter, Minimum Safe Mass, and Ion Exchange Module for the CVDF, HNF-SD-SNF-CSER-009, Rev. 1, Fluor Daniel Hanford, Incorporated, Richland, Washington.

Praga, A. N., 1998, 105-K Basin Material Design Basis Feed Description for Spent Nuclear Fuel Project Facilities, HNF-SD-SNF-TI-009, Rev. 1, Fluor Daniel Hanford, Incorporated, Richland, Washington.

Reilly, M. A., 1998, Spent Nuclear Fuel Project Technical Databook, Volume 1, Fuel, HNF-SD-SNF-TI-015, Rev. 6, Fluor Daniel Hanford, Incorporated, Richland, Washington.

Schmittroth, F., 1996, MCNP Criticality Validation and Bias for LEU Systems, WHC-SD-SNF-ANAL-013, Rev. 0, Westinghouse Hanford Company, Richland, Washington.

Schwinkendorf, K. N., 1997, Criticality Safety Evaluation Report for Spent Nuclear Fuel Processing and Storage Facilities, HNF-SD-SNF-CSER-005, Rev. 3, Fluor Daniel Hanford, Incorporated, Richland, Washington. 
HNF-SD-SNF-CSER-006 REV 2

APPENDIX A

\section{LISTINGS OF MCNP INPUT FUES}


HNF-SD-SNF-CSER-006 REV 2

This page intentionally left blank. 


\section{APPENDIX A}

\section{LISTINGS OF MCNP INPUT FILES}

Listed below are input files for MCNP cases rt0fp0a, rt0fp0b and sib42086, which are referenced in the body of this criticality safety evaluation report. These runs were made on. Hanford Scientific and Engineering Computing Center workstations. Each input file name has an "i" extension added to the case identifier (i.e., rt0fp0a.i), and the corresponding output file has a ".pr" extension. Electronic copies of the input and output files are archived in a project file.

\section{Case rtofpoa.}

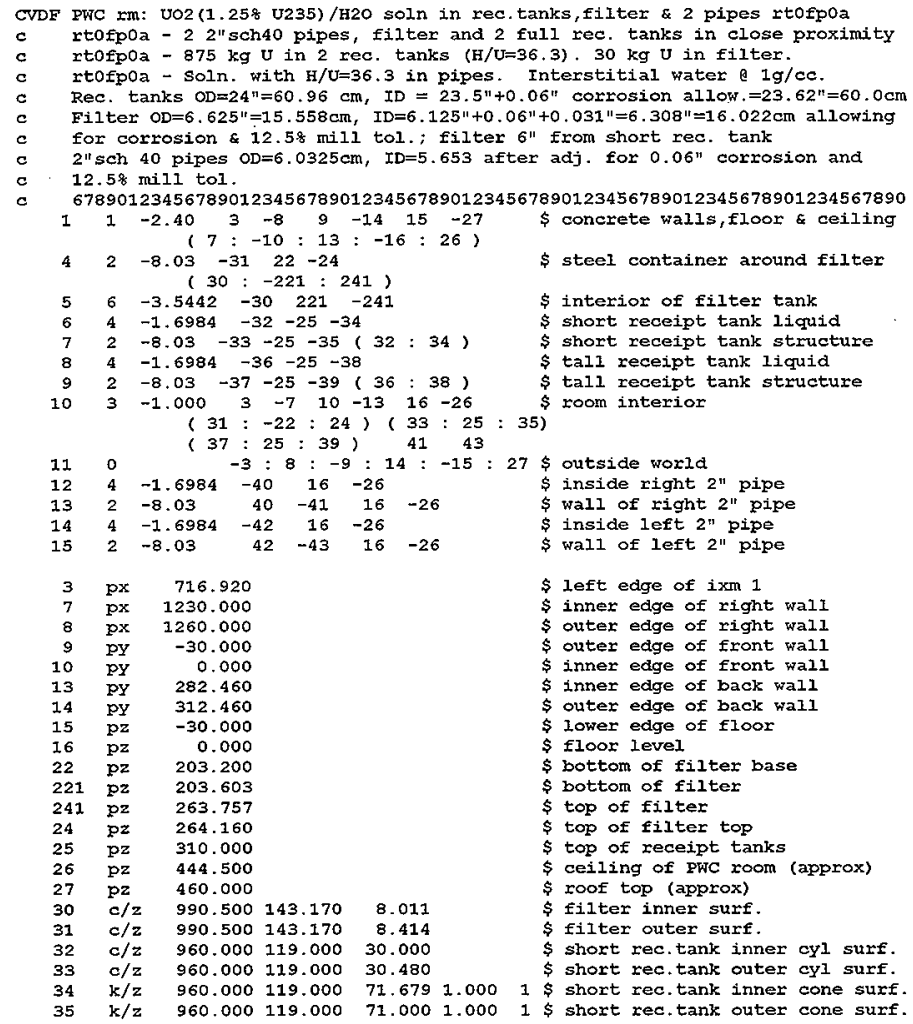




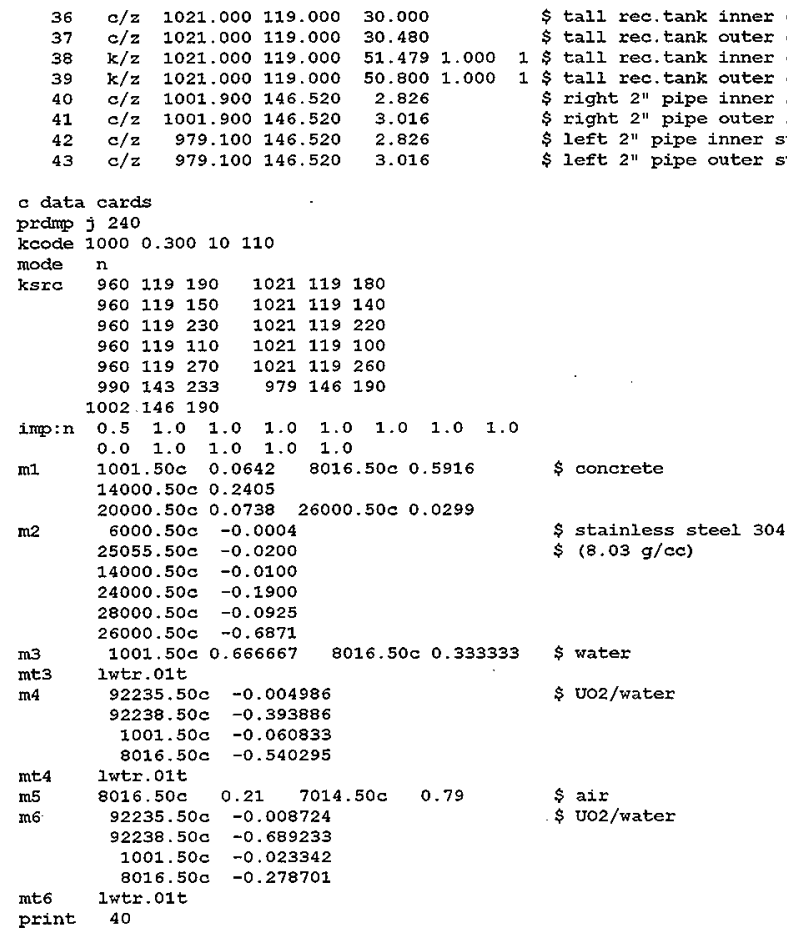

\section{Case rtofpob}

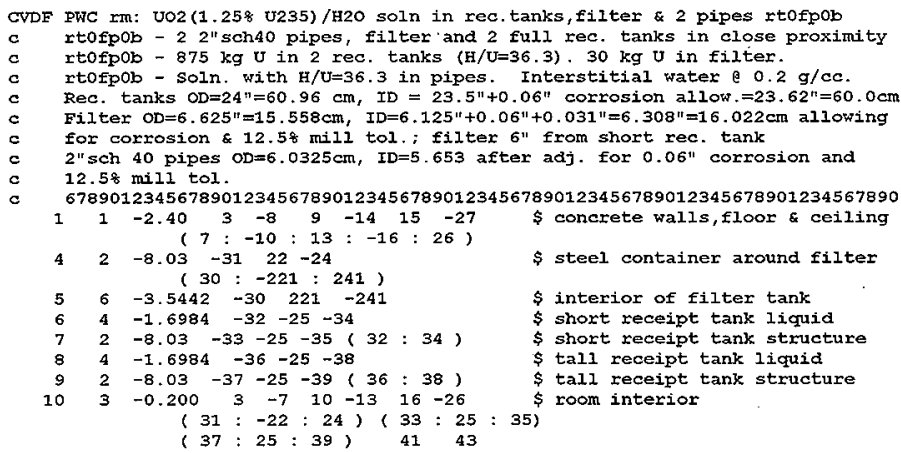




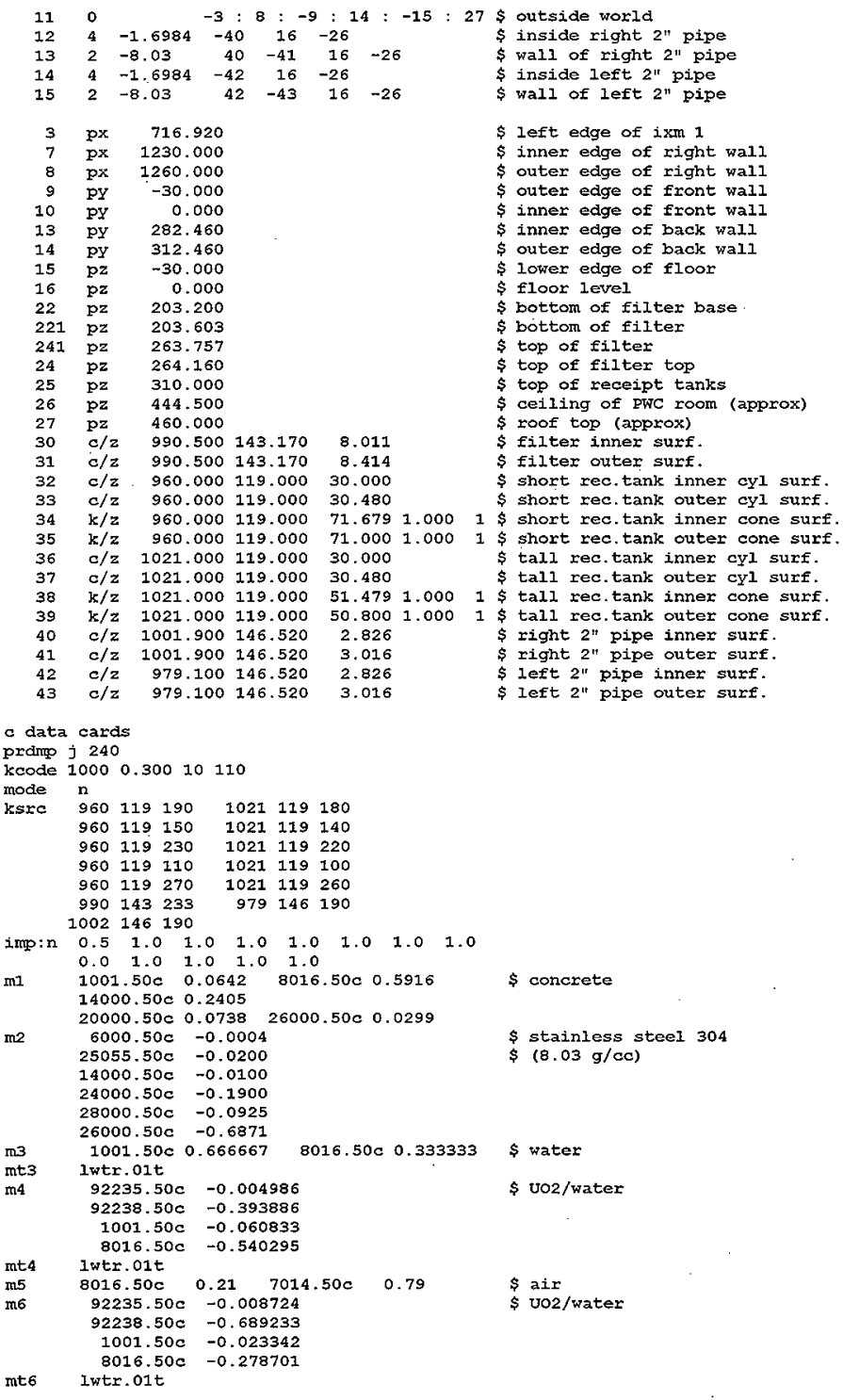


print 40

\section{Case slb42086}

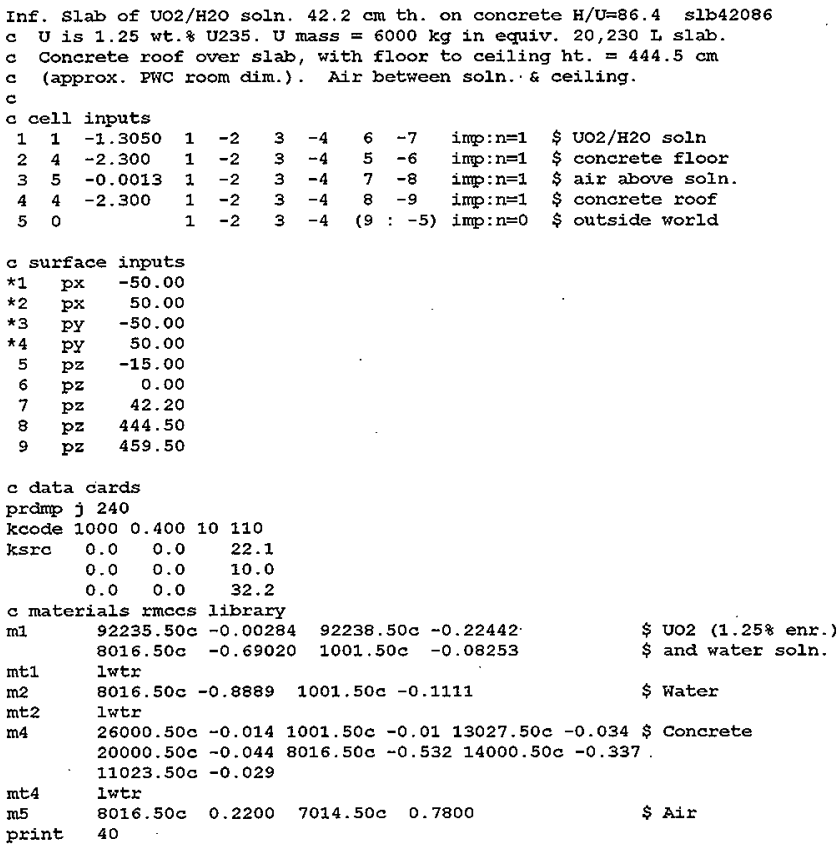

